\title{
IMPACTUL GEOPOLITIC AL TEHNOLOGIILOR EMERGENTE
}

\author{
THE GEOPOLITICAL IMPACT \\ OF THE EMERGING TECHNOLOGIES
}

\author{
Conf.univ.dr. Alba-Iulia Catrinel POPESCU*
}

\begin{abstract}
Pe lângă cortegiul de dezastre generat de pandemia de SARS-CoV-2, criza medicală globală a avut şi un efect pozitiv. Mai mult ca oricând a adus în prim-plan rolul fundamental jucat de cercetarea ştiinţifică şi tehnologică în progresul omenirii şi în apărarea sa în faţa ameninţărilor disruptive. Era tehnologică modernă a mileniului trei a schimbat relaţia om-mașină. În prezent, tehnologiile par a depăşi statutul lor de instrument de putere, transformându-se în jucători activi, care determină politici, acutizează mize, declanşează competiţii. Rând pe rând, inteligența artificială (IA), $5 \mathrm{G}$, securitatea cibernetică, robotica, semiconductorii şi microprocesoarele, cloud computing, combat cloud şi reţelele digitale au pus stăpânire pe activitățile umane și, prin extensie, pe dinamicile geopolitice internaționale. Astfel, problematicile subsecvente, politice, strategice, economice și sociale implică state, organizații internaţionale și companii private. Dinamicile competiției și ale cooperării internaționale sunt transformate. Articolul de faţă îşi propune să prezinte impactul tehnologiilor de ultimă generaţie asupra dinamicilor geopolitice contemporane şi, in extenso, asupra securităţii României.
\end{abstract}

In addition to the cortege of disasters generated by the SARS-COV II pandemic, the current global medical crisis has also had a positive effect. More than ever, it has brought up the fundamental role played by scientific and technological research in the progress of mankind and in its defense against disruptive threats. The modern technological age of the Third Millennium has changed the human-machine relationship. Today, technologies seem to go beyond their status as a tool of power, turning into active players, who determine policies, sharpen stakes, trigger competitions. Step by step, artificial intelligence (AI), $5 G$, cyber security, robotics, semiconductors and microprocessors, cloud computing, cloud combat and digital networks have taken over human activities and, by extension, international geopolitical dynamics. Also, all the subsequent consequences of the technological "sprint" (political, strategic, economic and social) involve states, international organizations and private companies. The dynamics of competition and international cooperation are being transformed. This article aims to present the impact of the state-of-the-art technologies on contemporary geopolitical dynamics and, in extenso, on Romania's security.

Cuvinte-cheie: geopolitica tehnologiilor; minereuri strategice; tehnologii disruptive; tehnologii emergente; inteligenţă artificială; România.

Keywords: technology geopolitics; strategic ores; disruptive technologie; emerging technologies; artificial intelligence; Romania.

Istoria umanităţii a fost scrisă de tehnologie. sau imperiu, tehnologiile au fost cele care au făcut Din Antichitate şi până în prezent, marile civilizaţii diferenţa. Prin urmare, putem spune că geoistoria şi, implicit, marile puteri s-au dezvoltat în jurul a doi umanităţii este, de fapt, o cronică a progresului piloni: geografie, prin topografie şi resurse (de apă, tehnologic, exprimat în plan politic şi strategic. hrană, energie, minerale), şi o tehnologie care să le $\quad$ I-au trebuit milenii omenirii ca să intre în era asigure un avantaj strategic în faţa competitorilor tehnologică modernă prin cazanul cu aburi sub direcţi. Dacă geografia a reprezentat pilonul fix, presiune, invenţia fizicianului francez Denis Papin imuabil, ,,axul geografic al istoriei” fiecărei naţiuni (1647-1713), din anul 1698, şi încă alte opt decenii pentru ca, pe rând, inginerul englez Thomas Newcomen (1663-1729), în 1712, şi, ulterior, *Universitatea Națională de Apărare „Carol I” e-mail:albapopescu1@gmail.com inginerul scoţian James Watt (1736-1819), în 1776, să construiască motorul cu aburi, maşinăria care avea să transforme radical societatea umană 
şi istoria sa prin nevoia de lemn şi de cărbune. Celei de-a doua revoluţii industriale nu i-au mai trebuit milenii pentru a se produce. După secole de descoperiri în domeniul câmpului electromagnetic şi al electricităţii, în mai 1834 inginerul prusac Moritz von Jacobi (1801-1874) a construit primul motor electric rotativ, deschizând o nouă etapă în dezvoltarea tehnologică a umanităţii şi lansând cursa pentru hidrocarburi. După alte câteva decenii, în anii secolului XX, omenirea a intrat în cea de-a treia revoluție industrială, odată $\mathrm{cu}$ inventarea tranzistorilor, a semiconductorilor şi a microprocesorului Intel 4004, care au adus computerizarea şi automatizarea industrială şi nevoia de cupru, germaniu, metale platinice. Iar, în prezent, digitizarea plasează omenirea în cea de-a patra revoluţieindustrială, a tehnologiei informaţiei, anunţând-o, deja, pe cea de-a cincea, a inteligenţei artificiale. Revoluţia industrială este conştientizată mai mult ca oricând în contextul actualei pandemii de SARS-CoV-2, când carantinarea a hipertrofiat rolul tehnologiei în traiul de zi cu zi al omenirii, de la dezvoltarea comerţului on-line, la dezvoltarea instrumentelor de e-learning şi de telemedicină.

Cum sunt reconfigurate dinamicile geopolitice de către actuala revoluţie industrială? Câtde adaptată este România pentru noua era tehnologică?

Noile materii prime: minereurile strategice

În primul rând, noile revoluţii industriale au adus cu ele noi materii prime şi, implicit, noi mize geopolitice.

Orice curs de geopolitică afirmă rolul determinant al resurselor în configurarea proceselor geopolitice. De exemplu, în secolul al XVIII-lea, goana după lemn de fag şi cărbune a adus Imperiul Habsburgic până în vecinătatea Mării Negre, unde a intrat în competiţie directă cu Imperiul Otoman. În secolul al XX-lea, goana după hidrocarburi a devenit imperativ strategic pentru toate marile puteri aflate în competiţie, transformând ţinutul costier al masei continentale a emisferei estice şi, mai ales, Orientul Mijlociu extins în teatre de operaţii militare, unele încă active şi în prezent, precum cele din Siria, Libia, Yemen, Somalia. Miza hidrocarburilor a creat state eşuate şi colapsate, migraţie transfrontalieră, secesionism, sărăcie, subdezvoltare şi emergenţa ideologiilor radicale ultraconservatoare, precum s-a putut constata din istoria recentă a spaţiului islamic, cel mai bogat în aceste resurse. Mai mult, hidrocarburile au construit state, precum monarhiile din zona Golfului Persic, au creat poli de putere regională (de exemplu, Iran şi Arabia Saudită) şi au constituit formate geoeconomice, geopolitice şi de securitate statale, precum Organization of the Petroleum Exporting Countries ${ }^{1}$ - Organizaţia Statelor Exportatoare de Petrol (OPEC), sau nonstatale, The International Association of Oil \& Gas Producers ${ }^{2}$ - Asociația Internațională a Producătorilor de Petrol și Gaze. Hidrocarburile au devenit instrumente de putere, atent jucate de producători. S-a demonstrat acest lucru în 1973, după războiul arabo-izraelian, de către Yom Kipur (6-26 octombrie 1973), când OPEC (prin Egipt, Siria şi Tunisia) a instituit embargo asupra livrărilor de petrol către statele care i-au sprijinit pe israelieni. Sau actuala criză a gazului, instrumentată de Gazprom, în baza dependenţei europene de gazul rusesc. O dependenţă, amplificată de cointeresarea unor parteneri europeni în proiectele de transport al gazelor naturale ruseşti în Europa, în detrimentul soluţiilor care ar fi diversificat sursele de gaz şi ar fi diminuat dependenţa de robinetele Gazprom, precum ar fi magistralele de gazoducte din cadrul Iniţiativei celor Trei Mari, aflate încă în stadiul de proiect $^{3}$ (BRUA, GIPL, Eastring Baltic Pipe etc.).

Acest mediu competiţional, care a dominat secolul al XX-lea şi primele decenii ale secolului actual, generat de goana după hidrocarburi, se reconfigurează sub impactul tehnologiilor emergente şi al nevoii de minereuri strategice, materiile prime de elecţie ale actualelor revoluţii industriale; aspect cunoscut la nivel european încă din 2010, când Grupul de Lucru Comunitar pentru Oferta de Materiale a emis raportul intitulat Critical Raw Materials for EU: Report of the Ad-hoc Working Group on defining critical raw materials ${ }^{4}$ - Materii prime critice pentru UE: Raportul Grupului de Lucru Ad-hoc privind definirea materiilor prime critice.

În acest raport, s-a afirmat că dezvoltarea tehnologică viitoare şi menţinerea competitivităţii economice europene depind de 41 de minereuri strategice, dintre care 14 sunt considerate critice - prin „critic” înţelegându-se „un material mineral sau mineral nealimentar, esenţial pentru securitatea economică şi naţională, care are o funcţie esenţială în fabricarea unui produs, a cărui absenţă ar avea consecinţe semnificative asupra economiei sau asupra securităţii naţionale" ${ }^{n}$. 
Emergenţa noilor materii prime a fost confirmată ulterior, în mai 2018, şi de SUA, prin Ordinul Executiv 13817 privind A Federal Strategy To Ensure Secure and Reliable Supplies of Critical Minerals - O strategie federală pentru asigurarea siguranței şi fiabilităţii furnizării de minerale critice (82 FR 60835) ${ }^{6}$ - al Departamentului de Interne al SUA (în coordonare cu un alt executiv), în care s-a publicat o listă cu 35 de minereuri? considerate critice pentru viitorul tehnologic american, printre care sunt incluse şi toate cele 14 minereuri nominalizate de europeni în propria lor listă.

În anii care au urmat, atât europenii, cât şi americanii au continuat raportările privind situaţia necesarului de minereuri strategice, al căror număr a crescut la 44 , aceste noi materii prime fiind menţionate în documentele strategice emise de forurile specializate de pe ambele ţărmuri ale spaţiului atlantic ${ }^{8}$.

Importanţa deosebită a acestor minereuri este generată, deopotrivă, de caracterul strategic al sectoarelor industriale, militare şi civile în care sunt utilizate (Anexa nr. 2), precum şi de controlul pe care puteri competitoare, emergente, îl exercită asupra extracţiei şi prelucrării acestora.

Precum se poate observa în harta din Figura 1 (şi în tabelul din Anexa nr. 1), China domină extracţia şi/sau procesarea a 29 de minereuri strategice, reprezentând două treimi din totalul minereurilor strategice critice de la nivel global (Figura 2). Pentru 24 dintre aceste minereuri, respectiv antimoniu, bismut, ceriu, disprosiu, erbiu, europiu, fluorspar, gadoliniu, galiu, germaniu, grafit nemetalic, holmiu, luteţiu, tuliu, iterbiu, magneziu, neodimiu, fosfor, praseodimiu, samariu, scandiu, siliciu metalic, terbiu şi tungsten, China domină piaţa globală în proporţie de peste $65 \%$ ! Iar în privinţa pământurilor rare, China exercită monopol pe întregul lanţ economic, de la extracţie şi prelucrare, la obţinerea de produse finite.

Prin urmare, China reprezintă principalul producător global de minereuri strategice, de care depinde avansul tehnologic mondial prezent şi viitor! La rândul lor, SUA controlează $88 \%$ din producţia mondială de beriliu, iar Rusia asigură $40 \%$ din producţia globală de paladiu.

Acestor jucători globali, li se adaugă state africane, precum Africa de Sud, care controlează producţia mondială de platină şi metale platinice cu cote de piaţă cuprinse între $71 \%$ și 93\%, R.D. Congo, cu zăcăminte uriaşe de cobalt, reprezentând $59 \%$ din rezervele globale, şi de columbo-tantalit şi tantal, reprezentând 33\%, şi Guineea, cu peste $33 \%$ din rezervele globale de bauxită. Sau state sud-americane, precum Brazilia, care domină $92 \%$ din producţia globală de niobiu, şi Chile, care asigură $44 \%$ din producţia globală de litiu. Există state în care China este deosebit de prezentă cu investiţii şi parteneriate, Africa de Sud şi

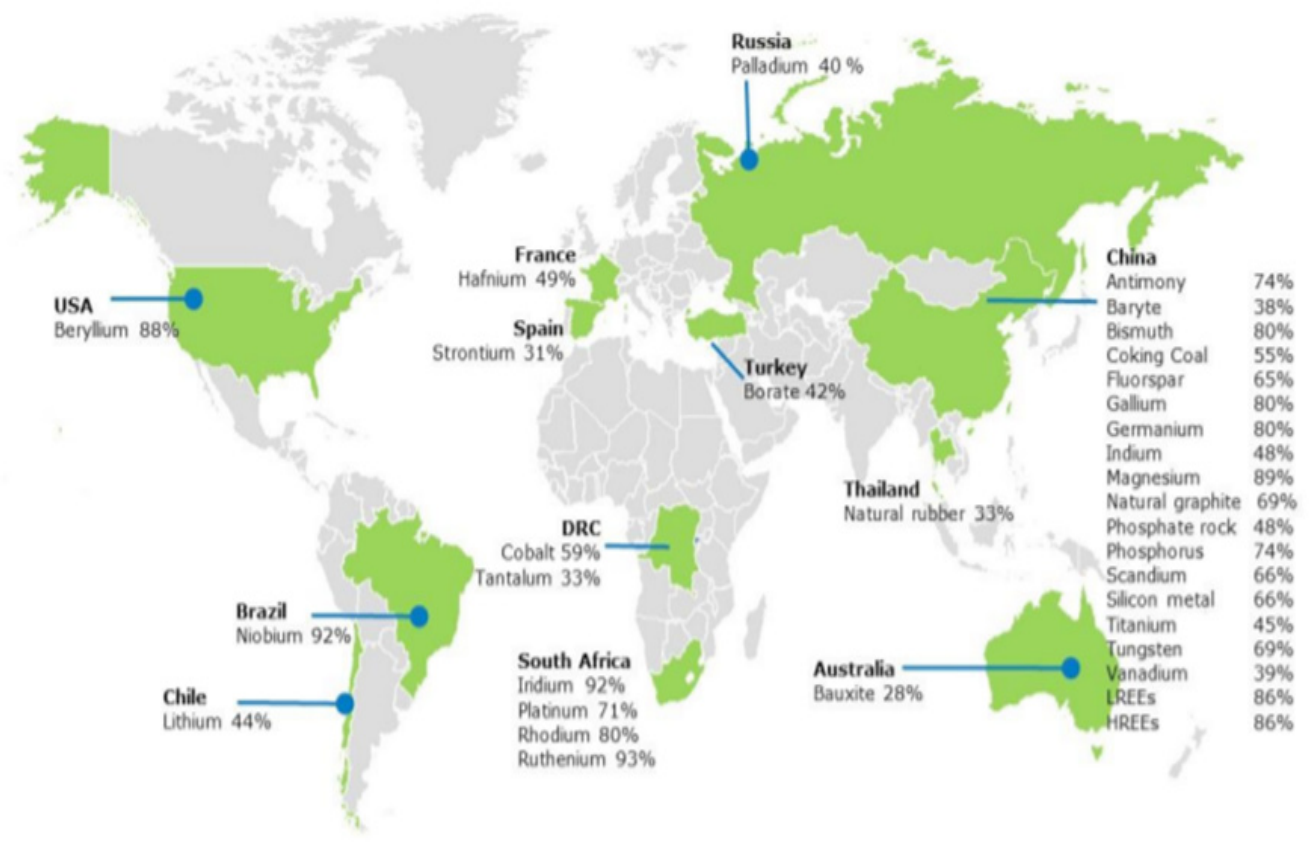

Figura 1 Distribuția geografică a producției de minereuri strategice în $2020^{9}$ 


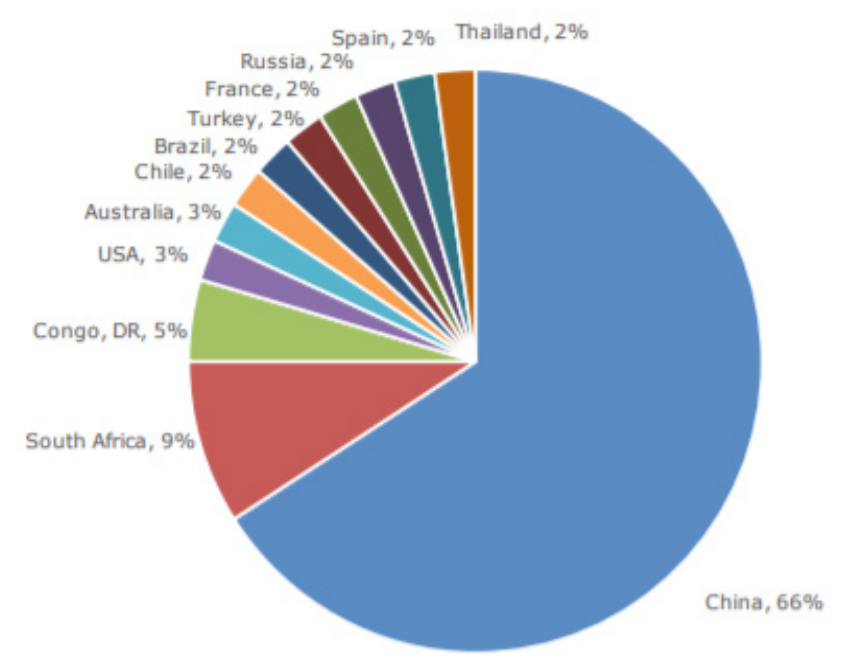

Figura 2 Ponderea pe piață a furnizării de materii prime critice la nivelul anului $2020^{10}$

Brazilia fiind capacitate atât în formatul BRICS ${ }^{11}$, cât şi în parteneriate strategice bilaterale ${ }^{12}$, alte state fiind vizate de strategiile investiţionale ale Beijingului ${ }^{13}$.

Se ştie că statele care domină producţia şi prelucrarea materiilor prime sunt principalele beneficiare ale revoluţiilor industriale, avantaj tradus în termeni de putere statală prin capacitatea de a menţine sau de a schimba actuala ordine mondială. În 1992, Deng Xiaoping (1904-1997), eminenţa cenuşie din spatele transformării Chinei în hegemonul asiatic de astăzi, spunea că ţara sa va beneficia de pe urma pământurilor rare întocmai ca Orientul Mijlociu, de pe urma petrolului - adică va transforma pământurile rare într-un izvor de prosperitate, într-o armă strategică, într-o sursă de putere statală. În harta din Figura 3, este prezentată capacitatea statelor europene de a-şi asigura necesarul de minereuri strategice din producţie proprie, care rareori depăşeşte $1 \%$ din necesar.

Şi, ne punem întrebarea: Cum vor beneficia statele europene de avantajele acestor noitehnologii, în condiţiile în care depind de importurile de materii prime din China şi din alte spaţii competitoare? Şi, cum vor folosi China şi celelalte puteri exportatoare atuul minereurilor strategice?

Un prim răspuns 1-am avut în 2010, când Beijingul a stopat, timp de două luni, exportul de pământuri rare către Japonia, în urma unui diferend diplomatic. Sau episodul în care China a oprit exporturile de pământuri rare către SUA, pe fondul unor fricţiuni comerciale ${ }^{15}$. Decizii care amintesc de politica energetică a Federaţiei Ruse faţă de statele „recalcitrante” din regiunea Istmului Ponto-
Baltic şi care demonstrează instrumentalizarea militară a minereurilor strategice de către China. Evident, consecinţele economice directe, suferite de industriile niponă şi americană, au obligat guvernele acestor state să caute furnizori alternativi în zone precum Africa, India, Australia, America de Sud şi să dezvolte tehnologii de extracţie submarină. Dar, în tot acest răstimp, din 2010 şi până în prezent, nu s-a remarcat o schimbare majoră de paradigmă în privinţa politicilor dezvoltate de occidentali şi de niponi în aceste areale alternative, în care China este tot mai prezentă şi mai dominantă, precum Africa Subsahariană, America de Sud, Marea Chinei de Sud, Oceanul Indian.

Dar nu doar China stăpâneşte ,,inelele" viitoarei dominaţii tehnologice. Spre exemplu, rezervele de paladiu ale Rusiei vor deveni extrem de importante în viitorul apropiat, în condiţiile conversiei surselor de energie dinspre tehnologiile poluante, bazate pe carbon, spre „energia verde”. La fel şi zăcămintele de osmiu ale Rusiei şi Africii de Sud. Ca urmare a capacităţii acestora de a absorbi hidrogenul ${ }^{16}$, cele două metale platinice vor deveni de neînlocuit în tehnologiile bazate pe pile de hidrogen, aspect care va crea o nouă dependenţă europeană de zăcămintele Rusiei şi ale Africii de Sud - statul african care deţine deja monopolul producţiei globale de platină, materie primă prezentă fie în compoziţia, fie în procesul de manufacturare a unei cincimi din ansamblul bunurilor de larg consum la nivel global $^{17}$.

Iar ambiţiile privind capabilităţile spaţiale, fără de care nicio putere viitoare nu va mai fi relevantă în plan internaţional, vor depinde de monopolul deţinut de Brazilia în privinţa producţiei globale de niobiu, metalul care generează cele mai intense câmpuri magnetice şi mai penetrante în adâncime, fiind un superconductor de tip II, generator de vortexuri şi supercurenţi magnetici la aplicarea unui câmp magnetic exterior, fără de care nu se pot concepe programe spaţiale, superaliaje, bolometre etc.

Jeremy Rifkin, economist american, spunea, în 2014, că tehnologia internetului şi energiile regenerabile, „motoarele” celei de-a treia revoluţii industriale, au anunţat sfârşitul dominaţiei combustibililor fosili şi al actualei ordini mondiale ${ }^{18}$. Nimic mai adevărat şi mai îngrijorător, dacă este să ne gândim că spaţiul islamic actual a fost configurat de hidrocarburi şi că state cu peste 1,2 miliarde de locuitori, din Orientul Mijlociu şi din Africa, în 
majoritate măcinate de dezechilibre structurale, de materii prime critice, pentru revoluţiile industriale sărăcie, de neopatriarhat şi subdezvoltare, depind în desfăşurare, Orientul Mijlociu fiind înlocuit de major de industria petrolieră. Ce se va întâmpla cu zona Asia-Pacific, urmată de Africa şi de cele două această uriaşă masă de oameni, cum se va realiza Americi. Sau, altfel spus, spaţiile de marginalitate,

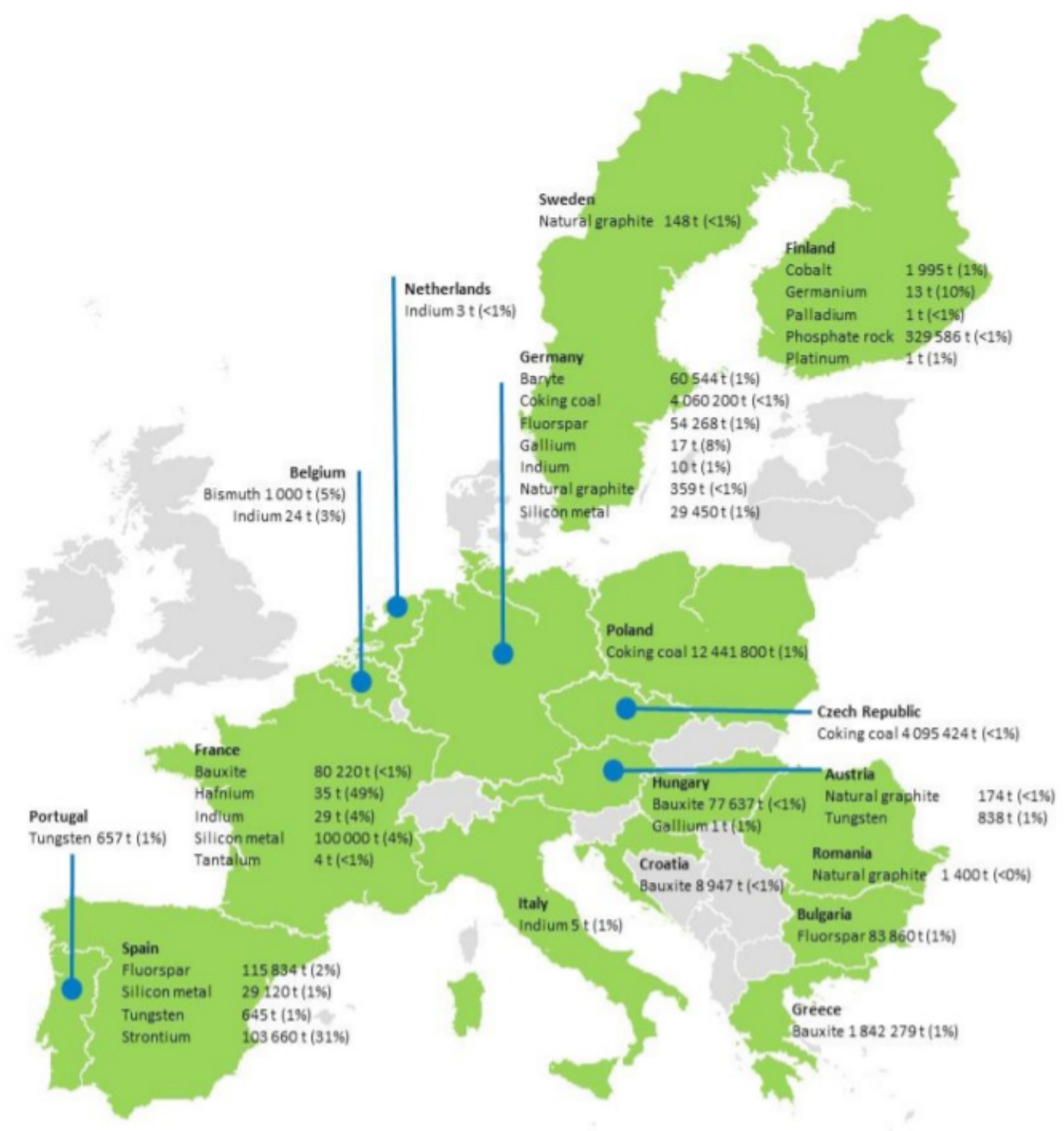

Figura 3 Producătorii europeni de minereuri strategice critice $^{14}$

reconversia tehnologică şi cât de încercată va fi ordinea mondială de o asemenea provocare? Greu de estimat. Cum la fel de greu de estimat va fi şi modul în care tehnologiile ,verzi” de producere a energiei vor coexista cu cele poluante pe piaţa globală şi cum se va reflecta acest binom în planul stabilităţii bursiere şi al stabilităţii sistemului financiar.

Prin urmare, putem spune că un prim impact geopolitic major al tehnologiilor emergente îl constituie o nouă ierarhie a spaţiilor globale relevante pentru controlul şi dominaţia surselor de descrise ca atare de teoreticianul spaţiilor globale, geopoliticianul american Saul B. Cohen (19252021), se transformă în spaţii de centralitate în ecuaţia dominaţiei globale contemporane. Dacă nu va dezvolta strategii coerente privind sursele alternative de minereuri strategice africane, sud-asiatice şi sud-americane, Europa va deveni tot mai irelevantă în planul puterii globale. Iar, aici trebuie amintit potenţialul de influenţă pierdut de România odată cu retragerea din Africa, din anii '90, potenţial care ar mai putea fi refăcut, dacă ar exista o strategie şi o voinţă politică în acest sens. 
Un al doilea impact geopolitic este generat de emergenţa Chinei, în calitate de deţinătoare a două treimi din resursele globale de minereuri strategice, de care depind tehnologiile de vârf militare şi civile. Un statut de dominaţie care nu poate fi trecut cu vederea şi care trebuie luat în calcul, în cazul unei eventuale confruntări deschise cu Beijingul.

Al treilea impact este legat de mizele controlului resurselor strategice alternative şi de riscul declanşării unor viitoare procese geopolitice destabilizatoare în areale mai mult sau mai puţin stabile din America de Sud, din zona Asia-Pacific, din Africa.

Şi, nu în ultimul rând, trebuie amintită marea provocare geopolitică adresată spaţiului islamic, poate cel mai puţin pregătit pentru o schimbare de paradigmă energetică şi pentru noile transformări societale, induse de tehnologiile disruptive. O destabilizare extinsă a acestui spaţiu, din imediata vecinătate a spaţiilor civilizaţionale ale masei continentale afro-eurasiatice ar însemna o ameninţare gravă la adresa securităţii şi stabilităţ̧ii în întreaga emisferă estică.

\section{Tehnologiile emergente disruptive}

Tehnologia disruptivă este o inovație care transformă semnificativ pieţele de desfacere, comportamentul consumatorilor, structura industrială a unui teritoriu. Întotdeauna o tehnologie disruptivă produce schimbări majore, extinse, structurale. Sintagma de ,tehnologii disruptive” a fost introdusă în circuitul public de către economistul american Clayton M. Christensen (1952-2020), în lucrarea The Innovator's Dilemma - Dilema inovatorului, publicată în 1997. De atunci, sintagma a devenit la modă în prezentările ce însoţesc propunerile de afaceri start-up, care caută să creeze un produs de mare atractivitate.

Dacă este să ne amintim de teza lui Jacques Attali, din lucrarea sa de referinţă Une brève histoire de l'avenir - Scurtă istorie a viitorului, începând cu secolul al XIII-lea, când au apărut primele sisteme tehnologice de producţie a hranei, şi până în prezent, dinamica polilor hegemoniei economice mondiale a fost generată de apariţia unor tehnologii disruptive, pe fondul unor crize economico-financiare. Prin urmare, progresul societăţii este rezultatul direct al factorului economic şi al celui tehnologic. Spre exemplu, spune Attali, hegemonia economică a migrat în secolul al XIV-lea dinspre Bruges
(1200 - 1350), locul în care s-a născut burghezia prin industrializarea producţiei de alimente şi prin descoperirea cârmei încorporate, spre Veneţia (1350 - 1500), locul din care a început cucerirea Orientului prin caravelele și galerele construite în şantierele sale navale şi unde s-au înfiinţat primele bănci, burse, case de comerţ, societăţi de asigurări. Apoi, în secolul al XVI-lea hegemonia economică a ajuns în Anvers (1500 - 1560), unde se descoperise tiparul mobil, care a industrializat producţia de cărţi, determinând reforma religioasă, şi, mai apoi, în Genova (1560 - 1620), unde se descoperise contabilitatea primară prin conturile de pierderi şi de profit. În secolul al XVIII-lea, hegemonia economică s-a mutat în Amsterdam (1620 - 1788), oraşul port care producea în serie nava numită „flueth”, ieftină şi rentabilă economic, căreia i se datorează marile descoperiri geografice, pentru ca, în secolul al XIX-lea, să ajungă în Londra (1788 - 1890), unde forţa aburului şi revoluţia manufacturieră au produs transformări structurale la nivel de societate prin emergenţa burgheziei, în calitate de clasă conducătoare, urmată de separarea puterilor în stat, de monarhia constituţională, de democraţia de piaţă, de proletarizarea ţăranilor, de apariţia marxismului şi extinderea colonialismului. Începând cu secolul al XX-lea, hegemonia economică a părăsit Europa, mutându-se în „Lumea Nouă", mai întâi în Boston (1890 - 1929), prin descoperirea motorului cu piston şi explozie şi a motorului electric, urmată de apariţia automobilelor, apoi în New York (1929 - 1980), prin utilizarea industrială a motorului electric, dezvoltarea industriei aparaturii electrocasnice şi audiovideo şi emanciparea femeilor, şi, în final în Los Angeles (1980 - prezent), prin descoperirea microcipului, microprocesorului, internetului, nanotehnologiilor, tehnologiilor spaţiale şi roboticii ${ }^{19}$.

Astăzi, omenirea se află în plină criză economică şi medicală pandemică. Crize peste care se suprapun noi tehnologii disruptive, precum comerțul electronic, site-urile de știri online şi platformele de social media, sistemele GPS, platformele de e-learning, de telemedicină, cloud computing, fintech şi Blockchain, tehnologia din spatele Bitcoin. Cât de aproape suntem de un nou pol al hegemoniei economice? Rămâne de văzut. Într-o societate tot mai tehnologizată, oricând poate apărea acea tehnologie care să conducă la o radicală transformare a pieţei şi a societăţii, indiferent de 
volumul resurselor start-upului. Mai mult, este foarte probabil ca inovaţia să vină mai degrabă din partea unor companii mai mici, flexibile, din state emergente, decât dintr-o companie consacrată, care tinde să se concentreze mai curând pe îmbunătăţiri progresive decât pe schimbări revoluționare. Şi, aşa după cum s-a văzut din succesiunea centrelor de putere globală, descrisă de Attali, tehnologiile disruptive potenţează transformarea hegemonică a statelor care beneficiază de acestea, chestionând statu-quoul sistemului internaţional şi ordinea mondială.

$\mathrm{O}$ astfel de inovaţie ar putea exercita efect de „lebădă neagră”, determinând consecinţe în lanţ, neaşteptate, care să oblige la adaptare rapidă sistemele de orice natură care nu reușesc să se adapteze efectelor tehnologiei disruptive, putându-se trezi în faţa unor pierderi majore. $\mathrm{O}$ astfel de inovaţie ar putea fi o sursă alternativă de energie care să înlocuiască în mod eficient hidrocarburile, sau o descoperire medicală care să vindece inflamaţiile cronice, scoţând din joc segmente întregi din Big Pharma.

Dar, până la acel moment al emergenţei unei noi hegemonii economice, tehnologiile actuale contribuie la un şi mai mare decalaj geopolitic şi geoeconomic între cele două lumi, ale statelor bogate şi sărace, ale oamenilor bogaţi şi săraci. În acest sens, este suficient să ne amintim că, la ora actuală, 592 de milioane de africani ${ }^{20}$, reprezentând $42,8 \%$ din populaţia continentului, nu au acces la electricitate şi că 2,6 miliarde de persoane de pe tot globul, reprezentând o treime din umanitate, nu au acces la condiţii civilizate de preparare a hranei $^{21}$. Situaţie departe de a se îmbunătăţi în perioada actuală, când pandemia SARS-CoV-2 a afectat macroechilibre economice globale, inclusiv în state cunoscute ca principali donori în fondurile de sprijin financiar pentru statele lumii a treia. De altfel, un raport al Fondului Monetar Internaţional, emis la sfârşitul anului 2020, afirmă că Africa are nevoie de 1.200 de miliarde de dolari pentru a se redresa după impactul pandemiei, iar experţii Băncii Mondiale susţin că 43 de milioane de africani sunt expuși riscului de sărăcie extremă, ca urmare a pandemiei ${ }^{22}$.

Prin urmare, primul şi cel mai important impact geopolitic al emergenţei tehnologiilor disruptive îl reprezintă adâncirea decalajului de dezvoltare dintre ţările bogate şi cele sărace. Astfel, bogaţii devin şi mai bogaţi prin concentrarea bogăţiei într-un număr restrâns de poli de putere tehnologică, în timp ce săracii devin şi mai săraci printr-o şi mai adâncă subdezvoltare, amplificată şi de accesul foarte scăzut la sanitaţie, la servicii medicale şi la educaţie. Pe de altă parte, în lumea bogaţilor, populaţia este tot mai puţină şi mai îmbătrânită, în timp ce în lumea săracilor, populaţia este tot mai numeroasă şi mai tânără. Cum se vor împăca aceste două faţete, demografică şi economică, ale lumii prezente şi viitoare? Cel mai probabil, vom asista la mari presiuni migraționiste dinspre sudul sărac spre nordul tot mai bogat. Şi, cum va rezista nordul sub asediul migraţiei ilegale transfrontaliere? Greu de anticipat. Este posibil să sfârşească într-un larg proces de fărâmiţare a spaţiilor globale şi să se întoarcă la esența ideii de suveranitate statală şi de ordine westphaliană, la fel după cum este posibil ca acest fapt să conducă la o reconfigurare din temelii a ordinii mondiale într-o guvernanţă globală, capabilă să gestioneze decalajele şi provocările de securitate, generate de acestea.

Dar, nu doar între state se vor înregistra decalaje, ci chiar şi în interiorul societăţilor. Spre exemplu, în SUA, aproximativ un sfert dintre adulții cu venituri mici, sub 30.000 de dolari pe an (reprezentând 24\% din populaţia adultă totală) spun că nu dețin nici măcar un smartphone. Aproximativ patru din zece adulţi cu venituri mai mici nu au servicii de bandă largă la domiciliu (43\%) sau un computer desktop sau laptop (41\%). Și, majoritatea americanilor cu venituri mai mici nu deţin tablete. Prin comparație, fiecare dintre aceste tehnologii este aproape omniprezentă în rândul adulților din gospodăriile care câştigă minimum 100.000 de dolari anual. Iar, în aprilie 2020, în condiţiile carantinei impuse de pandemie, 59\% dintre părinţii americani cu venituri mai mici au declarat că s-au confruntat cu cel puțin unul dintre cele trei obstacole digitale în calea asigurării educaţiei online a copiilor lor, respectiv lipsa unui internet fiabil, lipsa unui computer acasă sau utilizarea unui smartphone pentru finalizarea temelor școlare ${ }^{23}$. Prin urmare, în contextul societăţii digitizate, apare un nou tip de diviziune, de ordin digital, şi un nou indicator, de accesibilitate la servicii digitale. Unde va duce acest decalaj? Cel mai probabil, la o şi mai mare polarizare socială şi, odată cu aceasta, la o radicalizare a păturilor sărace, care se vor simți tot mai marginalizate şi mai incapabile să îşi împlinească nevoile sociale. 
Prin urmare, un al doilea impact geopolitic al tehnologiilor actuale îl constituie adâncirea discrepanţei dintre păturile sociale, polarizarea şi mai intensă a societăţii, amplificarea tensiunilor sociale şi radicalizarea păturilor sărace, urmate de creşterea riscului apariţiei mișcărilor populiste şi extremiste, fenomene sociale, traduse geopolitic prin amplificarea forţelor centrifuge care predispun la conflicte, secesionism, eşuare statală.

Şi, nu în ultimul rând, trebuie amintită dependenţa tot mai crescută la nivel global de producătorii subansamblelor care intră în componența produselor tehnologice. Prin urmare, nu există doar o dependenţă faţă de furnizorii de materii prime, ci şi o dependenţă globală faţă de producătorii de subansamble. Spre exemplu, în domeniul producţiei de microprocesoare, cei doi lideri de piață, $\mathrm{TSMC}^{24}$, din Taiwan, și Samsung, din Coreea de Sud, acoperă aproape $75 \%$ din contractele de producție la nivel mondial ${ }^{25}$, TSMC fiind şi cel mai mare producător global de cipuri electronice de contact, de care depind producţiile unor companii precum Apple sau Huawei ${ }^{26}$. Mai mult, administraţia taiwaneză investește masiv în cercetare tehnologică şi, în mod special, în dezvoltarea de noi tehnologii de fabricație, folosind inteligența artificială (AI), o politică de stat care plasează disputata republică insulară din imediata vecinătate a Chinei în eşalonul fruntaş al statelor care vor beneficia de pe urma celei de-a cincea revoluţii industriale. Ce s-ar putea întâmpla însă, dacă Taiwanul şi Coreea de Sud ar fi antrenate în războaie regionale? Care ar putea fi impactul geoeconomic al dispariţiei de pe piaţă a semiconductorilor şi microprocesoarelor fabricate în cele două ţări? Răspunsul nu poate fi decât unul singur, un impact cataclismic, dependenţa globală de subansamblele produse în această regiune a globului transformându-se într-un instrument de putere pentru aparent vulnerabilele naţiuni.

Prin urmare, un al treilea impact geopolitic al înaltelor tehnologii se referă la transformarea lor în adevărate instrumente de putere, cu excepţională valoare defensivă. Atât prin dependenţele globale de producătorii de subansamble, a căror cădere ar putea genera prăbuşirea lanţurilor globale de producție a unor industrii întregi, cu efecte incalculabile geoeconomice şi, automat, cu consecințe geopolitice care ar putea evolua până la declanşarea unor războaie hegemonice, cât şi prin avansul tehnologic, care aduce cu sine prosperitate şi creează premisele maximizării puterii statale. Şi, nu în ultimul rând, dependențele tehnologice pot configura alianţe, coaliţii, arhitecturi de securitate, menite să prezerve statu-quoul şi să asigure securitatea unui spaţiu tehnologic de maximă importanţă geoeconomică şi geopolitică. Şi, mai putem afirma că, în actualul mediu internaţional tehnologizat, statusul tehnologic ar trebui să fie tratat ca sursă şi instrument de putere de sine stătător în orice analiză de securitate profesionistă.

\section{Războiul modern în era inteligenței artificiale}

Actualele revoluţii industriale îşi pun amprenta şi asupra modului de purtare a războiului, poate cel mai vechi mod de a face politică cu alte mijloace ${ }^{27}$. In acest sens, analistul american Harlan Ullman, teoretician al concepului de massive attack of disruption (MAD) - atac masiv perturbator -, consideră că războiul viitorului va fi unul al acestor atacuri disruptive, componente ale doctrinei shock and awe - şoc şi groază -, prin care voinţa de luptă a adversarului este paralizată de anvergura copleşitoare a atacului. Aceste atacuri perturbatoare masive, descrisedeUllmancafiind,,celde-alcincilea cavaler al Apocalipsei", sunt produsul a şapte forţe perturbatoare principale: eşuarea guvernării, schimbările climatice, spaţiul cibernetic, reţelele de socializare, dronele, terorismul şi îndatorarea explozivă $^{28}$. Forţe care vizează vulnerabilităţile societale, care acţionează sinergic prin potenţare reciprocă şi care au impact masiv asupra populaţiei. Forţe care acţionează asupra ,ţesăturii” de interese şi de dependenţe, create de interconexiunile societăţii globalizate, hipertehnologizate. Forţe care îngrozesc tocmai prin multitudinea de efecte, pe principiul dominoului, generate de interferenţa tehnologiei, de difuzia puterii şi de destructurarea statelor westphaliene $^{29}$.

Războiul modern, de a cincea generaţie, este o confruntare a rețelelor digitale extinse, interconectate și interdependente, care asigură, în timp real, culegerea şi transmiterea de informaţii, detectarea, evaluarea impactului și transmiterea comenzii; a combat cloud-urilor, care permit extragerea și adăugarea de date prin activarea digitală a platformelor cheie de luptă; a tacticilor de luptă multidomeniu, în cele cinci domenii operaționale sinergice - terestru, maritim, aerian, 
spațial și cibernetic; a războiului de fuziune prin vulnerabilitățile generate de războiul de comandă și control, precum fluxurile de informații suplimentare, incompatibilitățile software și vulnerabilitățile intrinseci la atac și înșelăciune.

Toate aceste noi faţete ale războiului sunt rezultatul emergenţei tehnologiilor ultimelor revoluţii industriale şi aduc cu ele o nouă şi înfricoşătoare provocare. Dacă, în privinţa competiţiei pentru materiile prime critice, un stat poate alege sau nu să se alăture cursei pentru resurse, iar, în privinţa avansului tehnologic, poate încerca să se alinieze în rândul puterilor tehnologice emergente, în ceea ce priveşte războiul, accesul la tehnologia de vârf şi la inteligenţa artificială face diferenţa dintre supravieţuire şi anihilare.

Ce înseamnă acest lucru în planul securităţii şi al geopoliticii?

În primul rând, ideea de securitate colectivă şi de alianţe, singurele formule prin care statele pot fi capabile să reziste în faţa sprintului tehnologic actual.

În al doilea rând, o potenţială glisare spre o configurare civilizațională, de tip nomos tehnologic, a spaţiilor globale tehnologice. Aspect care atrage cu sine un număr mare de actori internaționali, uniți prin interese, principii şi valori comune, iar, în caz de confruntare, imense teatre de operaţii, masive forţe angrenate în luptă, distrugeri şi costuri uriaşe $^{30}$.

În al treilea rând, o potenţială reconfigurare a sferelor de influenţă, dictate de polii de putere tehnologică, civilă şi militară, care vor fi adevăraţii viitori hegemoni ai planetei. Şi, implicit, o potenţială nouă ordine mondială, care poate scoate din joc hegemonii actuali, dacă nu vor fi capabili să ţină pasul cu avansul tehnologic, şi care poate să aducă în prim-plan alţi hegemoni - state sau alianţe.

\section{În loc de încheiere: care este impactul geopolitic al acestor tehnologii emergente pentru România?}

În ultimii 30 de ani, România a pierdut pe toate palierele de putere tehnologică.

A părăsit continentul african, unde era jucător geostrategic activ şi unde ar fi putut folosi capitalul de influență, creat cu mari eforturi financiare în perioada comunistă. Aceeași viziune de politică externă s-a aplicat şi în cazul altor spaţii ale lumii a treia, în care România era jucător înainte de
1989, din America de Sud şi Asia de Sud. Astăzi, acel capital de influenţă s-ar fi putut transforma în instrument de putere, având în vedere viitoarea cursă pentru furnizori alternativi de minereuri strategice din Africa, Asia şi America de Sud.

În planul cercetării ştiinţifice, România înregistrează un recul îngrijorător, prin lipsa unei strategii care să urmărească alinierea tehnologică a ţării la media statelor occidentale. În anul 2021, în clasamentul Global Inovation Index 2021, din cele 132 de state din întreaga lume, inclusiv din zonele măcinate de conflicte sau subdezvoltate din Africa, Asia şi America de Sud, România s-a situat pe locul 48. Chiar şi aşa, poziţia sa relativ fruntaşă, a fost rezultatul, mai curând, al infrastructurii (electrificare, sanitaţie, infrastructuri de transport) şi al performanţelor economice decât al capitalului uman şi cercetării propriu-zise - unde se situează pe poziţia 76 în clasamentul parţial -, al gradului de sofisticare al pieţei - unde se află pe locul 76 - şi al creativităţii - unde ocupă poziţia $72^{31}$. Prin urmare, poziţia României în clasamentul amintit nu reflectă nicidecum o performanţă, nici chiar mediocră, în domeniul cercetării ştiinţifice, dacă este să privim îngrijorătorul loc 76 , adică în a doua jumătate a clasamentului, pe care s-a situat în această privinţă.

În societatea hipertehnologizată a viitorului, alinierea şi supremaţia tehnologică vor constitui criterii de ierarhizare şi de evaluare în procesul decizional de tip real-politic. De ce ar consuma cineva timp şi resurse pentru a sprijini, a proteja sau a se alia cu un stat aparţinând lumii a treia tehnologice, poziţionat geopolitic în zona gri a Istmului Ponto-Baltic, în limesul dintre vechile imperii ale Europei? Sau, altfel spus, pentru cât timp beneficiile unui astfel de sprijin/alianţă vor depăşi costurile garantării securităţii unui stat subdezvoltat tehnologic? Care ar fi acele resurse atât de atractive care 1-ar putea recomanda pentru un astfel de sprijin, sau cât de importantă va continua să fie poziţia sa geostrategică, în contextul atât de fluidului mediu internaţional?

Pe de altă parte, toate aspectele discutate mai sus se pot transforma în provocări la adresa securităţii naţionale a României, de la cursa pentru minereuri strategice şi riscul destabilizării spaţiului islamic, sub impactul unei noi paradigme energetice mondiale, la migraţia ilegală transfrontalieră masivă şi până la tehnologiile disruptive şi războiul 
de a cincea generaţie - care nu mai este un subiect de anticipaţie, având deja loc în Transcaucazia, între azeri şi separatiștii armeni din NagornoKarabakh, în septembrie-noiembrie 2020. Provocări de securitate care riscă să încline balanţa dintre forţele centrifuge şi cele centripete active la nivelul teritoriului național şi care are ca rezultat menţinerea statu-quoului.

Prin urmare, în societatea tehnologizată postpandemică, viitorul României nu mai poate fi decât unul tehnologic, aspect care presupune elaborarea unei strategii de recalibrare a sistemului de educaţie şi cercetare la noile provocări ale erei inteligenţei artificiale şi înaltelor tehnologii militare şi civile, în care componenta cyber (cyberwarfare, cyberdefense, cybereducation) să joace un rol fundamental, şi, foarte important, a unei strategii de finanţare şi dezvoltare a unor platforme de cercetare tehnologică şi fundamentală care să atragă spre cercetare capitalul uman din ţară, diaspora şi spaţii limitrofe.

\section{NOTE:}

1 https://www.opec.org/opec_web/en/, accesat la 31.10.2021. $2 \mathrm{https}: / / w w w . i o g p . o r g / a b o u t-u s /$, accesat la 31.10.2021.

$3 * * *$ The Three Seas Initiative - Priority Interconnection Projects, http://three-seas.eu/wp-content/uploads/2018/09/ LIST-OF-PRIORITY-INTERCONNECTION-PROJECTS2018.pdf, accesat la 31.10.2021.

$4{ }^{* * *}$ Critical Raw Materials for EU: Report of the Ad-hoc Working Group on defining critical raw materials, http://www.euromines.org/files/what-we-do/sustainabledevelopment-issues/2010-report-critical-raw-materials-eu. pdf, accesat la 31.10.2021.

5 ***A Federal Strategy To Ensure Secure and Reliable Supplies of Critical Minerals, Executive Office of the President on 12/26/2017, https://www.federalregister.gov/ documents/2017/12/26/2017-27899/a-federal-strategy-toensure-secure-and-reliable-supplies-of-critical-minerals, accesat la 18.06.2019, apud Alba-Iulia Catrinel Popescu, Analize incomode, Editura Militară, București, 2020, p. 96.

6 Ibidem.

7 ***Final List of Critical Minerals 2018, Interior Department on 05/18/2018, https://www.federalregister.gov/ documents/2018/05/18/2018-10667/final-list-of-criticalminerals-2018, accesat la 18.06.2019.

$8{ }^{* * *}$ Critical Raw Material, https://ec.europa.eu/ growth/sectors/raw-materials/areas-specific-interest/criticalraw-materials_nl; ${ }^{* * *}$ Critical Raw Materials Resilience: Charting a Path towards greater Security and Sustainability, https://ec.europa.eu/docsroom/documents/42849; ***Critical Minerals and U.S. Public Policy, https://www.everycrsreport. com/reports/R45810.html, accesate la 31.10.2021.

$9{ }^{* * *}$ European Commission, Study on the EU's list of Critical Raw Materials - Final Report (2020), file:///C:/ Users/Alba.Popescu/Downloads/CRM\%201ist\%202020_ Final\%20Report.pdf, p. 6, accesat la 31.10.2021.

\section{Ibidem.}

11 Organizație de cooperare denumită prin acronimul referitor la țările membre: Brazilia, Rusia, India, China și Africa de Sud.

12 ***China and South Africa Hold the Tenth Strategic Dialogue 2019/10/30, https://www.fmprc.gov.cn/mfa_eng/ wjb_663304/zzjg_663340/fzs_663828/xwlb_663830/ t1712585.shtml; China maintains with Brazil long-term and stable strategic partnership based on mutual benefit, https:// www.fmprc.gov.cn/mfa_eng/ziliao_665539/3602_665543/3 604_665547/t18025.shtml, accesate la 31.10.2021.

13 Odette Magnet, Chinese investment in Chile sparks opportunities, concerns, Al Jazeera, 03.09.2021, https:// www.aljazeera.com/economy/2021/9/3/chinese-investmentin-chile-sparks-opportunities-concerns; Aaron Ross, Helen Reid, Congo's \$6 bln China mining deal 'unconscionable', says draft report, Reuters, 08.10.2021, https://www. reuters.com/business/congos-6-bln-china-mining-dealunconscionable-says-draft-report-2021-10-08/, accesate la 31.10.2021.

$14{ }^{* * *}$ European Commission, Study on the EU's list of Critical Raw Materials - Final Report (2020), file:///C:/ Users/Alba.Popescu/Downloads/CRM\%20list\%202020_ Final\%20Report.pdf, p. 7.

15 Gus Lubin, China just banned exports of Rare Earth Minerals to the US, Business Insider, 19.10.2010, http:// www.businessinsider.com/chinas-has-just-started-ban-of-rareearth-metal-exports-to-the-us-2010-10, accesat la 20.12.2014.

16 Kohei Kusada, Miho Yamauchi, Hirokazu Kobayashi, Hiroshi Kitagawa, Yoshiki Kubota, HydrogenStorage Properties of Solid-Solution Alloys of Immiscible Neighboring Elements with Pd, J. Am. Chem. Soc., 2010, 132 (45), p. 1 5896-1 5898, October 27, 2010, http://pubs. acs.org/doi/abs/10.1021/ja107362z, accesat la 17.06.2015.

17 ***Platinum-Group Metals, U.S. Geological Survey, National Minerals Information Center, 2019, https://prd-wret. s3-us-west-2.amazonaws.com/assets/palladium/production/ atoms/files/mcs-2019-plati.pdf, accesat la 17.06.2019.

18 Jeremy Rifkin, The Third Industrial Revolution. How lateral power is transforming energy, the economy and the world, http://www.thethirdindustrialrevolution.com/, accesat la 20.12 .2014 .

19 Jacques Attali, Scurtă istorie a viitorului, Editura Polirom, Iaşi, 2016, pp. 49 - 75.

$20 * * *$ Population without access to electricity in Africa from 2000 to 2020 (in millions), https://www.statista.com/ statistics/1221698/population-without-access-to-electricityin-africa/, accesat la 01.11.2021.

21 ***SEforALL Analysis of SDG7 Progress - 2021, https://www.seforall.org/system/files/2021-08/AnalysisSDG7-Progress-2021.pdf, accesat la 01.11.2021.

22 [BBC] "Africa 'needs $\$ 1.2 \mathrm{tn}$ ' to recover coronavirus losses", 10.10.2020, https://www.bbc.com/news/worldafrica-54491053, accesat la 01.11.2021.

23 Emily A. Vogels, Digital divide persists even as Americans with lower incomes make gains in tech adoption, Pew Research Center, https://www.pewresearch.org/fact$\operatorname{tank} / 2021 / 06 / 22 /$ digital-divide-persists-even-as-americanswith-lower-incomes-make-gains-in-tech-adoption/, accesat la 31.10.2021. 
24 Acronim al Taiwan Semiconductor Manufacturing Company.

25 Matthias Sander, "Ready, set, compute: The global race for microchip dominance", Neue Bürcher Zeitung, 26.04.2021, https://www.nzz.ch/english/microchip-producti on-grows-increasingly-important-in-us-china-ld.1613831, accesat la 31.10.2021.

26 Sarah O'Meara, "From plastic toys to Industry 4.0: How Taiwan is using science to upgrade its manufacturing", Nature, 15.01.2020, https://www.nature.com/articles/d41586020-00060-1, accesat la 31.10.2021.

27 Parafrază după Carl Philipp Gottlieb von Clausewitz, Despre război, Editura Antet, Bucureşti, 2001.

28 Harlan Ullman, Al cincilea cavaler al apocalipsei şi noul MAD, Editura Militară, Bucureşti, 2021, p. 30.

29 Alba-Iulia Catrinel Popescu, „Observații despre războiul de a cincea generație şi cel de-al doilea război din Nagorno-Karabakh", Buletinul Universității Naționale de Apărare „, Carol I” nr. 3, 2021.

30 Samuel P. Huntington, The Clash of Civilizations and the Remaking of World Order, Simon \& Schuster, 1996, passim.

$31 * * *$ Global Innovation Index2021, Tracking Innovation through the COVID-19 Crisis, https:/www.wipo. int/edocs/pubdocs/en/wipo_pub_gii_2021.pdf, accesat la 31.10.2021.

$32 * * *$ European Commission, Study on the EU's list of Critical Raw Materials-Final Report (2020), file://C:/Users/ Alba.Popescu/Downloads/CRM\%20list\%202020_Final\%20 Report.pdf, accesat la 31.10.2021, p. 5.

33 *** "Platinum and its use", Total Materia, http:// www.totalmateria.com/page.aspx? ID $=$ CheckArticle\&site $=\mathrm{kt}$ n\&NM=237, accesat la 20.05.2015, apud Alba-Iulia Catrinel Popescu, op.cit., p. 99.

34 ***Platinum-Group Metals, U.S. Geological Survey, National Minerals Information Center, 2019, https://prd-wret. s3-us-west-2.amazonaws.com/assets/palladium/production/ atoms/files/mcs-2019-plati.pdf, accesat la 17.06.2019.

35 Kohei Kusada, Miho Yamauchi, Hirokazu Kobayashi, Hiroshi Kitagawa, Yoshiki Kubota, Hydrogen-Storage Properties of Solid-Solution Alloys of Immiscible Neighboring Elements with Pd, J. Am. Chem. Soc., 2010, 132 (45), p. 1 5896-1 5898, October 27, 2010, http://pubs.acs.org/doi/ abs/10.1021/ja107362z, accesat la 17.06.2015.

36 Luke Burgess, Investing in Rhodium, the World's Most Expensive Metal: The World's Most Exotic Precious Metal, Wealthdaily, 21.05.2010, http://www.wealthdaily. com/articles/rhodium-investing/2507, accesat la 18.06.2015.

37 Terence Bell, Metal Profile: Ruthenium, http:// metals.about.com/od/properties/a/Metal-Profile-Ruthenium. htm, accesat la 18.06.2015; Tania Bossi, 25 Proeminent and Promising Applications Using Platinum Group Metals, IPA FACT SHEET, 2012, http://www.stillwatermining.com/ pdf/25_Applications_of_PGMs.pdf, accesat la 20.05.2015.

$3 \overline{8} * * *$ Antimony, Mineral Commodity Summaries, February 2019, USGS Survey, https://prd-wret.s3-us-west-2. amazonaws.com/assets/palladium/production/s3fs-public/ atoms/files/mcs-2019-antim.pdf, accesat la 19.06.2019.

39 Brian W. Jaskula, Beryllium, U.S. Geological Survey, Mineral Commodity Summaries, February 2019, https:// prd-wret.s3-us-west-2.amazonaws.com/assets/palladium/ production/s3 fs-public/atoms/files/mcs-2019-beryl.pdf, accesat la 19.06.2019.

40 Kim B. Shedd, Cobalt, U.S. Geological Survey, Mineral Commodity Summaries, February 2019, https:// prd-wret.s3-us-west-2.amazonaws.com/assets/palladium/ production/s3fs-public/atoms/files/mcs-2019-cobal_0.pdf, accesat la 18.06.2019.

41 Gallium - Ga, Lenntech, http://www.lenntech.com/ periodic/elements/ga.htm, accesat la 28.06.2015.

42 Brian W. Jaskula, Gallium, U.S. Geological Survey, Mineral Commodity Summaries, January 2019, https:// s3-us-west-2.amazonaws.com/prd-wret/assets/palladium/ production/mineral-pubs/gallium/mcs-2018-galli.pdf, accesat la 28.06.2015.

43 Micheal W. George, Germanium, U.S. GEOLOGICAL SURVEY MINERALS YEARBOOK-2003, http:// minerals.usgs.gov/minerals/pubs/commodity/germanium/ germamyb03.pdf, p. 2, accesat la 28.06.2015.

$44 * * *$ Mineral Commodity Summaries 2015, US Geological Survey, January 2015, http://minerals.usgs.gov/ minerals/pubs/mcs/2015/mcs2015.pdf, accesat la 28.06.2015, p. 74; ***Indium Element Facts, Chemicool, http://www. chemicool.com/elements/indium.html, accesat la 28.06.2015, apud Alba-Iulia Catrinel Popescu, op.cit., p. 19.

45 E. Lee Bray, Magnesium Metal, US Geological Survey, Mineral Commodity Summaries, February 2019, https://prd-wret.s3-us-west-2.amazonaws.com/assets/ palladium/production/atoms/files/mcs-2019-mgcom.pdf, accesat la 28.06.2019.

$46 * * * N i o b i u m$ (Columbium) and Tantalum: Statistics and Information, http://minerals.usgs.gov/minerals/pubs/ commodity/niobium/, accesat la 29.06.2015.

47 Abraham J. Padilla, Niobium (Columbenit), US Geological Survey, Mineral Commodity Summaries, February 2019, https://prd-wret.s3-us-west-2.amazonaws. com/assets/palladium/production/s3fs-public/atoms/files/ mcs-2019-niobi.pdf, accesat la 29.06.2019.

48 Abraham J. Padilla, Tantalum, US Geological Survey, Mineral Commodity Summaries, February 2019, https:// prd-wret.s3-us-west-2.amazonaws.com/assets/palladium/ production/s3fs-public/atoms/files/mcs-2019-tanta.pdf,

49 Kim B. Shedd, Tungsten, Mineral Commodity Summaries, US Geological Survey, February 2019, https:// prd-wret.s3-us-west-2.amazonaws.com/assets/palladium/ production/atoms/files/mcs-2019-tungs.pdf, accesat la 30.06.2019.

50 Michele E. McRae, Fluorspar, US Geological Survey, Mineral Commodity Summaries, February 2019, https:// prd-wret.s3-us-west-2.amazonaws.com/assets/palladium/ production/s3fs-public/atoms/files/mcs-2019-fluor_0.pdf, accesat la 30.06.2019.

51 Graphite Applications, FORTUNE GRAPHITE INC, http://www.fortunegraphite.com/graphite_uses.php, accesat la 30.06.2015.

52 Marc Humphries, Rare Earth Elements: The Global Supply Chain, Congressional Research Service, 08.06.2012, http://www.fas.org/sgp/crs/natsec/R41347.pdf, accesat la 24.12.2014. 


\section{BIBLIOGRAFIE}

***A Federal Strategy To Ensure Secure and Reliable Supplies of Critical Minerals, Executive Office of the President on 12/26/2017, https://www. federalregister.gov/documents/2017/12/26/201727899/a-federal-strategy-to-ensure-secure-andreliable-supplies-of-critical-minerals

***China and South Africa Hold the Tenth Strategic Dialogue 2019/10/30, https://www. fmprc.gov.cn/mfa_eng/wjb_663304/zzjg_663340/ fzs_663828/xwlb_663830/t1712585.shtml

*** China maintains with Brazil long-term and stable strategic partnership based on mutual benefit, https://www.fmprc.gov.cn/mfa_eng/ziliao 665539/3602_665543/3604_665547/t18025.shtml

***Critical Raw Material, https://ec.europa. eu/growth/sectors/raw-materials/areas-specificinterest/critical-raw-materials_nl

***Critical Minerals and US Public Policy, https://www.everycrsreport.com/reports/R45810.html

***Critical Raw Materials for EU: Report of the Ad-hoc Working Group on defining critical raw materials, http://www.euromines.org/files/whatwe-do/sustainable-development-issues/2010report-critical-raw-materials-eu.pdf

***Critical Raw Materials Resilience: Charting a Path towards greater Security and Sustainability, https://ec.europa.eu/docsroom/documents/42849

***European Commission, Study on the EU's list of Critical Raw Materials - Final Report (2020), file://C:/Users/Alba.Popescu/Downloads/ CRM\%20list\%202020_Final\%20Report.pdf

***Final List of Critical Minerals 2018, Interior Department on 05/18/2018, https://www. federalregister.gov/documents/2018/05/18/201810667/final-list-of-critical-minerals-2018

***Global Innovation Index2021, Tracking Innovation through the COVID-19 Crisis, https:// www.wipo.int/edocs/pubdocs/en/wipo_pub_ gii_2021.pdf

***Population without access to electricity in Africa from 2000 to 2020 (in millions), https:// www.statista.com/statistics/1221698/populationwithout-access-to-electricity-in-africa/

*** "Platinum and its use", Total Materia, http://www.totalmateria.com/page.aspx?ID=Chec $\mathrm{kArticle} \&$ site $=\mathrm{ktn} \& \mathrm{NM}=237$

***Platinum-Group Metals, U.S. Geological Survey, National Minerals Information Center,
2019, https://prd-wret.s3-us-west-2.amazonaws. com/assets/palladium/production/atoms/files/mcs2019-plati.pdf

***Platinum-Group Metals, U.S. Geological Survey, National Minerals Information Center, 2019, https://prd-wret.s3-us-west-2.amazonaws. com/assets/palladium/production/atoms/files/mcs2019-plati.pdf

***SEforALL Analysis of SDG7 Progress 2021, https://www.seforall.org/system/files/202108/Analysis-SDG7-Progress-2021.pdf

***The Three Seas Initiative - Priority Interconnection Projects, http://three-seas.eu/wpcontent/uploads/2018/09/LIST-OF-PRIORITYINTERCONNECTION-PROJECTS-2018.pdf

[BBC] "Africa 'needs $\$ 1.2 \mathrm{tn}$ ' to recover coronavirus losses", 10.10.2020, https://www.bbc. com/news/world-africa-54491053

Attali Jacques, Scurtă istorie a viitorului, Editura Polirom, Iaşi, 2016.

Bell Terence, Metal Profile: Ruthenium, http:// metals.about.com/od/properties/a/Metal-ProfileRuthenium.htm

Burgess Luke, Investing in Rhodium, the World's Most Expensive Metal: The World's Most Exotic Precious Metal, Wealthdaily, 21.05.2010, http://www.wealthdaily.com/articles/rhodiuminvesting/2507

Humphries Marc, Rare Earth Elements: The Global Supply Chain, Congressional Research Service, 08.06.2012, http://www.fas.org/sgp/crs/ natsec/R41347.pdf

Huntington Samuel P., The Clash of Civilizations and the Remaking of World Order, Simon \& Schuster, 1996.

Kusada Kohei, Miho Yamauchi, Hirokazu Kobayashi, Hiroshi Kitagawa, Yoshiki Kubota, Hydrogen-Storage Properties of Solid-Solution Alloys of Immiscible Neighboring Elements with Pd, J. Am. Chem. Soc., 2010, 132 (45), October 27, 2010, http://pubs.acs.org/doi/abs/10.1021/ ja107362z

Lubin G., China just banned exports of Rare Earth Minerals to the US, Business Insider, 19.10.2010, http://www.businessinsider.com/ chinas-has-just-started-ban-of-rare-earth-metalexports-to-the-us-2010-10

Magnet O., Chinese investment in Chile sparks opportunities, concerns, Al Jazeera, 03.09.2021, https://www.aljazeera.com/economy/2021/9/3/ 
chinese-investment-in-chile-sparks-opportunitiesconcerns

O'Meara Sarah, "From plastic toys to Industry 4.0: How Taiwan is using science to upgrade its manufacturing", Nature, 15.01.2020, https://www. nature.com/articles/d41586-020-00060-1

Popescu Alba Iulia Catrinel, „Observații despre războiul de a cincea generație şi cel de-al doilea război din Nagorno-Karabakh", Buletinul Universității Naționale de Apărare ,, Carol I”, nr. 3, 2021.

Popescu Alba-Iulia Catrinel, Analize incomode, Editura Militară, Bucureşti, 2020.

Rifkin Jeremy, The Third Industrial Revolution. How lateral power is transforming energy, the economy and the world, http://www. thethirdindustrialrevolution.com/

Ross A., Reid H., Congo's \$6 bln China mining deal 'unconscionable', says draft report, Reuters, 08.10.2021, https://www.reuters.com/business/ congos-6-bln-china-mining-deal-unconscionablesays-draft-report-2021-10-08/
Sander Mathias, "Ready, set, compute: The global race for microchip dominance", Neue Bürcher Zeitung, 26.04.2021, https://www.nzz.ch/ english/microchip-production-grows-increasinglyimportant-in-us-china-ld.1613831

Ullman Harlan, Al cincilea cavaler al apocalipsei şi noul MAD, Editura Militară, Bucureşti, 2021.

Vogels Emily A., Digital divide persists even as Americans with lower incomes make gains in tech adoption, Pew Research Center, https://www. pewresearch.org/fact-tank/2021/06/22/digitaldivide-persists-even-as-americans-with-lowerincomes-make-gains-in-tech-adoption/.

https://www.opec.org/opec_web/en/

https://www.iogp.org/about-us/

http://minerals.usgs.gov/

http://www.fortunegraphite.com/graphite_ uses.php

http://www.lenntech.com/periodic/elements

https://prd-wret.s3-us-west-2.amazonaws.com/

Anexa nr. 1

TIPURILE DE MINEREURI STRATEGICE ŞI PRINCIPALII PRODUCĂTORI GLOBALI AI ACESTORA LA NIVELUL ANULUI 2020 32

\begin{tabular}{|c|c|c|c|c|c|c|c|c|c|}
\hline & Minereu & Stadiu & $\begin{array}{l}\text { Principal } \\
\text { producător global }\end{array}$ & $\begin{array}{c}\text { Cota de } \\
\text { piată }\end{array}$ & & Minereu & Stadiu & $\begin{array}{l}\text { Principal } \\
\text { producător } \\
\text { global }\end{array}$ & $\begin{array}{l}\text { Cota de } \\
\text { piaţă }\end{array}$ \\
\hline 1 & Antimoiu & E & China & $74 \%$ & 23 & Magneziu & $P$ & China & $89 \%$ \\
\hline 2 & Bariu & $E$ & China & $38 \%$ & 24 & Grafit natural & $E$ & China & $69 \%$ \\
\hline 3 & Bauxită & $E$ & Australia & $28 \%$ & 25 & Cauciuc natural & $E$ & Thailanda & $33 \%$ \\
\hline 4 & Beriliu & $E$ & SUA & $88 \%$ & 26 & Neodimiu & $E$ & China & $86 \%$ \\
\hline 5 & Bismut & $P$ & China & $80 \%$ & 27 & Niobiu & $P$ & Brazilia & $92 \%$ \\
\hline 6 & Borat & $E$ & Turcia & $42 \%$ & 28 & Paladiu & $P$ & Rusia & $40 \%$ \\
\hline 7 & Ceriu & $E$ & China & $86 \%$ & 29 & Fosfaţi & E & China & $48 \%$ \\
\hline 8 & Cobalt & $E$ & R.D. Congo & $59 \%$ & 30 & Fosfor & $P$ & China & $74 \%$ \\
\hline 9 & Cocs & $E$ & China & $55 \%$ & 31 & Platina & $P$ & Africa de Sud & $71 \%$ \\
\hline 10 & Disprosiu & $E$ & China & $86 \%$ & 32 & Praseodimiu & $E$ & China & $86 \%$ \\
\hline 11 & Erbiu & $E$ & China & $86 \%$ & 33 & Rodiu & $P$ & Africa de Sud & $80 \%$ \\
\hline 12 & Europiu & $E$ & China & $86 \%$ & 34 & Ruteniu & $P$ & Africa de Sud & $93 \%$ \\
\hline 13 & Fluorspar & $E$ & China & $65 \%$ & 35 & Samariu & E & China & $86 \%$ \\
\hline 14 & Gadoliniu & $E$ & China & $86 \%$ & 36 & Scandiu & $P$ & China & $66 \%$ \\
\hline 15 & Galiu & $P$ & China & $80 \%$ & 37 & Siliciu metalic & $P$ & China & $66 \%$ \\
\hline 16 & Germaniu & $P$ & China & $80 \%$ & 38 & Tantal & $E$ & R.D. Congo & $33 \%$ \\
\hline 17 & Hafniu & $P$ & Franţa & $49 \%$ & 39 & Terbiu & $\mathrm{E}$ & China & $86 \%$ \\
\hline 18 & $\mathrm{Ho}, \mathrm{Tm}, \mathrm{Lu}, \mathrm{Yb}$ & $E$ & China & $86 \%$ & 40 & Titan & $P$ & China & $45 \%$ \\
\hline 19 & Indiu & $P$ & China & $48 \%$ & 41 & Tungsten & $P$ & China & $69 \%$ \\
\hline 20 & Iridiu & $P$ & Africa de Sud & $92 \%$ & 42 & Vanadiu & $E$ & China & $39 \%$ \\
\hline 21 & Lantan & $E$ & China & $86 \%$ & 43 & Ytriu & $\mathrm{E}$ & China & $86 \%$ \\
\hline 22 & Litiu & $P$ & Chile & $44 \%$ & 44 & Stronţiu & $\mathbf{E}$ & Spania & $31 \%$ \\
\hline \multicolumn{10}{|c|}{ Legendă } \\
\hline \multicolumn{2}{|c|}{ Stadiu } & \multicolumn{8}{|c|}{$E=$ extracție; $P=$ procesare } \\
\hline \multicolumn{2}{|c|}{ Metale rare grele } & \multicolumn{8}{|c|}{ disprosiu, erbiu, europiu, gadoliniu, holmiu (Ho), luteţiu (Lu), terbiu, tuliu (Tm), iterbiu (Yb), itriu } \\
\hline \multicolumn{2}{|c|}{ Metale rare usoare } & \multicolumn{8}{|c|}{ ceriu, lantan, neodimiu, praseodimiu, samariu } \\
\hline \multicolumn{2}{|c|}{ Metale platinice } & \multicolumn{8}{|c|}{ iridiu, paladiu, platină, rodiu, ruteniu } \\
\hline
\end{tabular}




\section{APLICAȚIILE INDUSTRIALE ALE MINEREURILOR STRATEGICE}

Precum am prezentat în volumul intitulat Analize incomode, publicat în 2020, la Editura Militară:

- platina are o largă întrebuinţare atât în industria militară, cât şi în cea civilă. În principal, este utilizată, în industria constructoare de maşini, la obţinerea de convertoare catalitice auto, destinate reducerii emisiilor de carbon (se mai numeşte „,metal de mediu”), dar şi la obţinerea pilelor de combustie cu catalizatori de platină pentru submarine, nave, autovehicule, turbine aeronautice ${ }^{33}$ etc.;

- paladiul este utilizat ca substituent mai ieftin al platinei în producţia de convertori catalitici ${ }^{34}$ şi $^{-}$ în cercetările privind fuziunea la rece şi posibilitatea creării de surse alternative de energie, pe modelul low-energy nuclear reactions (LENR, reacţiilor nucleare cu energie joasă), ca urmare a capacităţii sale de a absorbi hidrogenul ${ }^{35}$.

- rodiul este întrebuinţat la producerea convertorilor catalitici pentru motoare Diesel (unde nu poate fi înlocuit) ${ }^{36}$, ruteniul este utilizat în industria IT şi electronică, la producţia de hard diskuri şi superconductori ${ }^{37}$ etc.

- Principala aplicaţie industrială a antimoniului constă în producţia de echipamente şi de substanţe ignifuge, unde este materia primă de bază şi de neînlocuit ${ }^{38}$.

- Beriliul este utilizat în producţia de armament termonuclear, surse de neutroni pentru acceleratoare de particule, reactoare CANDU, în producţia de aeronave, de sateliţi, de nave spaţiale, de rachete; în producţia de oglinzi de dimensiuni mari, pentru sateliţi meteorologici, şi de oglinzi mici, pentru sisteme militare de ghidaj optic şi sisteme de control al focului, telescoape spaţiale, panouri solare; în producţia de sisteme de deminare navală sau terestră, de radare de mare putere, de unelte pentru sisteme generatoare de microunde de mare putere, de semiconductori ${ }^{39}$ etc.

- Cobaltul este folosit în industria militară, la fabricarea armamentului nuclear pe bază de Co, a magneţilor permanenţi de mare putere pentru industria militară; a aliajelor speciale pentru industria aerospaţială, în medicină (proteze), la confecționarea bijuteriilor (aliaj cu platină), în obținerea pigmenţilor pentru sticlărie, ceramică, a radioizotopilor cu scop medicinal ${ }^{40}$ etc.

- Galiul (extras preponderent din bauxită şi sfalerită) stabilizează plutoniul, fiind utilizat la confecţionarea miezului bombelor nucleare ${ }^{41}$. În principal este utilizat la producţia de dispozitive optoelectronice, semiconductori şi diode cu emisie luminoasă LED, circuite integrate utilizate în industria militară, industria IT şi telecomunicaţii ${ }^{42}$ etc.

- Germaniul este utilizat în producţia de fibre optice infraroşii folosite în industria de apărare la fabricarea sistemelor de ghidaj balistic, a sistemelor de ochire şi în industria civilă, la producţia sistemelor de vizualizare nocturnă, spectroscoapelor cu infraroşii, detectoarelor cu infraroşii, dispozitivelor optoelectronice, în polimerizarea catalitică în procesul de obţinere a nanofibrelor şi în alte procese chimice $^{43}$ etc.

- Indiul este utilizat în producţia de aliaje metalice folosite în aplicaţii criogenice şi înalt vacuumate, în industria electronică şi electrotehnică: touch-screen-uri, LCD-uri, flat-screen-uri, semiconductori, monitoare pentru computere, panouri solare, baterii, superconductori, diode LED ${ }^{44}$ etc.

- Principalele utilizări ale magneziului sunt în industria militară, la producţia de focoase, bombe incendiare, dispozitive pirotehnice, rachete, în industria aerospaţială (aliaje uşoare de aluminiumagneziu), în industria farmaceutică ${ }^{45}$ etc.

- Niobiul este utilizat în producţia de oţeluri speciale (niobiul creşte rezistenţa oţelului), în industria constructoare de autovehicule, în construcţia de gazoducte, la producţia de superaliaje pentru industria aerospaţială (motoare pentru rachete şi avioane, turbine de gaz, subansamble pentru rachete, sisteme de combustie, sisteme turbo) ${ }^{46}$, la programe spaţiale (Apollo, Gemini), în producţia de superconductori pentru echipamente medicale de rezonanţă magnetică nucleară, acceleratoare de particule, lasere 
FLASH, bolometre pentru detectarea radiaţiilor electromagnetice din banda de frecvenţă THz, utilizate la construcţia telescoapelor de mare putere ${ }^{47}$ etc.

- Tantalul este folosit la confecţionarea de instrumente de tăiat, cuptoare pentru furnale, lentile pentru camere digitale, telefonie mobilă, ochelari, filtre de tip Surface Acoustic Wave, pentru telefonie mobilă, televiziune, aparatură audiovideo ${ }^{48}$ etc.

- Tungstenul este utilizat la confecţionarea garniturilor sticlă-metal, a filamentelor pentru lămpi electrice, tuburilor catodice, cuptoarelor electrice, iluminaţiei fluorescente, obiectivelor cu raze X; la obţinerea de aliaje speciale pentru rachete, în industria petrolieră, minieră, metalurgică, la fabricarea vopselurilor speciale, lubrifianţilor pentru temperaturi înalte $\left(500^{\circ} \mathrm{C}\right)^{49}$ etc.

- Florsparul este folosit, în industria chimică, la obţinerea acidului fluohidric, utilizat în producţia de substanţe de refrigerare, agenţi de spumare, produşi chimici pe bază de fluorură de carbon şi fluor, în industria metalurgică la obţinerea de fier, oţel şi alte metale; extrage impurităţile de tip sulf şi fosfor din minereuri şi creşte fluiditatea zgurii, este folosit și în industria optică la producţia de lentile pentru microscoape, telescoape, camere video, inclusiv pentru spectrul radiaţiilor ultraviolete ${ }^{50}$ etc.

- Grafitul natural este utilizat la confecţionarea de cărămizi refractare, creuzete refractare, căptuşeli pentru furnale, în producţia de baterii (litiu-ion, zinc-carbon) şi baterii pentru electronice portabile (laptopuri, tablete, telefoane mobile, CD-playere portabile), în producţia de oţeluri speciale, de lubrifianţi, de garnituri de frână, unde înlocuieşte azbestul (cancerigen) ${ }^{51}$ etc.

- pământurile rare (REM), reprezentate de lantan, ceriu, praseodimiu, neodimiu, promeţiu, samariu, europiu, gadoliniu, terbiu, disprosiu, holmiu, erbiu, tuliu, iterbiu, luteţiu, la care se adaugă scandiul şi itriul, au, ca principală aplicaţie militară, producţia de magneţi permanenţi pe bază de samariu-cobalt şi de neodimiu-fier-brom.

Magneţii pe bază de neodimiu, cei mai puternici magneţi permanenţi, sunt esenţiali în producţia de sisteme de arme ofensive şi defensive. Magneţii pe bază de samariu sunt esenţiali în producţia de sisteme de ghidaj balistic, de bombe inteligente şi de componente aeronautice. Magneţii pe bază de terbiu, gadoliniu, neodimiu, disprosiu sunt componente fundamentale la fabricarea de generatori pentru turbine eoliene, componente electrice şi electronice, în industria IT, de telecomunicaţii şi de comunicaţii prin satelit. Disprosiul este vital în asigurarea permanenţei magnetismului la temperaturi foarte înalte ${ }^{52}$. 